\title{
A Review on Coronary Bioresorbable Vascular Scaffold System
}

\author{
K Revathi ${ }^{1}$, U Swathilakshmi ${ }^{1}$, P Shailaja ${ }^{1}$, J Vijaya Ratna ${ }^{1}$, Blessy A Daniel ${ }^{2}$ and Prasanth $\mathrm{S}^{2 *}$ \\ ${ }^{1}$ Andhra University College of Pharmaceutical Sciences, India \\ ${ }^{2}$ S3V Vascular Technologies Pvt. Ltd., India
}

Submission: June 15, 2017; Published: July 03, 2017

*Corresponding author: Prasanth S, Clinical research Department, S3V Vascular Technologies Pvt. Ltd., Bangalore, India, Email: prashanth.srirangam@gmail.com

\begin{abstract}
Historically biodegradable materials for implants which serve as a temporary function have been used in therapeutic medicine in areas that includes wound closure, interventional technologies, drug delivery, oncology and cardiovascular surgery and were designed to overcome the disadvantages of permanent metallic based devices. Various types of materials are used for the development of scaffold strut like polymers (poly-L-Lactic acid, tyrosine poly carbonate) and alloys (Mg, platinum). BVS (bioresorbable vascular scaffold) are mainly useful for the restoration of functional endothelial coverage, allows the restoration of physiological vasomotion, allow to graft stented segments of coronary artery, enables prevention of acute recoil or occlusion, provide inhibition of in segment restenosis through efficient drug elusion and no foreign material left behind. Along with the advantages there are some disadvantages like higher target lesion revascularization rates compared with Drug Eluting Stents (DES).
\end{abstract}

Keywords: BVS; CAD; Restenosis; Revascularization; Intervention technology

\section{Introduction}

Coronary Artery Disease (CAD) is the most common type of heart disease. It is the leading cause of death. CAD happens when the arteries that supply blood to heart muscle become hardened and narrowed. This is due to the buildup of cholesterol and other material, called plaque on their inner walls. As it grows, less blood can flow through the arteries. As a result, the heart muscle can't get the blood or oxygen it needs. Over time, CAD can also weaken the heart muscle and contribute to heart failure and arrhythmias. Heart failure means the heart can't pump blood well to the rest of the body. Arrhythmias are changes in the normal beating rhythm of the heart [1]. CAD treated by surgery and other procedures includes balloon angioplasty, stent placement and coronary artery bypass surgery [2]. Percutaneous transluminal coronary angioplasty (PTCA) is a minimally invasive procedure used to open blocked coronary arteries to improve blood flow and allow blood to circulate to the heart muscle. Using a balloon to dilate a stenotic vessel usually results in a small dissection in the vessel wall. Prior to the introduction of stent technology, larger dissection often resulted in the patient requiring emergency bypass surgery, whereas stents can now be used to support the vessel wall from the inside. This re-establishes normal blood flow and avoids the need for emergency surgery. Another problem typically associated with balloon angioplasty is restenosis of a previously widened section of a blood vessel (in-stent restenosis). When balloon angioplasty results in a dissection forming inside a diseased vessel, this can lead to an overgrowth of scar tissue, which in turn can result in restenosis of a previously treated section. Although the introduction of stents has helped to counteract this problem, the use of bare metal stents is associated with restenosis in up to a third of all treated sections, with the exact rate of restenosis dependent upon the characteristics of the previously treated section (length of lesion, vessel diameter, degree of calcification). Brachytherapy and drug eluting stents were considered to be the potential treatment method for the treatment of ISR but were associated with risk of edge restenosis and late thrombosis. As the role of stents is temporary only till healing, reendothelialization and no benefits are found thereafter researchers have targeted the biodegradable and corrodible products used in medicine to develop biodegradable and bioabsorbable stents or Bioabsorbable vascular scaffolds [3-10]. Following Figure 1 shows the technological evolution with advantages and risks associated in Angioplasty treatment. 


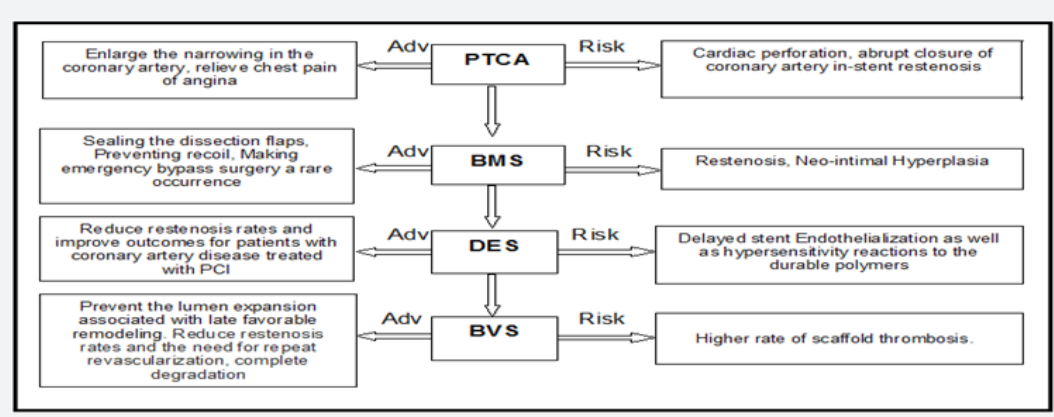

Figure 1: Technological evolution with advantages and risks associated in angioplasty treatment.

\section{Bioresorbable Vascular Scaffolds (BVS)}

Dramatic advances in Bioabsorbable materials and technology have delivered the potential for a fully absorbable scaffold, which is able to mechanically support the coronary artery for a predetermined time period. BVS represent a new concept of providing transient vessel support with drug delivery capability but theoretically without the long term limitations of metallic DES [11-15]. Such as permanent vessel caging and possible malapposition, risk of late ST, neoatherosclerosis, and local inflammation also permanent metallic stenting precludes the possibility of later surgical revascularization prevents late lumen enlargement, results in inhibiting non invasive imaging of coronary arteries using Computed tomography (CT) and Magnetic resonance imaging (MRI). Currently there are four materials used in BVS, of which lactide polymers particularly Poly-L-lactic acid form the basis of several devices and are the most extensively investigated other materials include magnesium poly anhydrates (salicylic acid and adipic acid) and poly carbonates (amino acids) [16-21]. Following Figure 2 shows how BVS implanted coronary blood vessel looks after complete degradation of stent material.

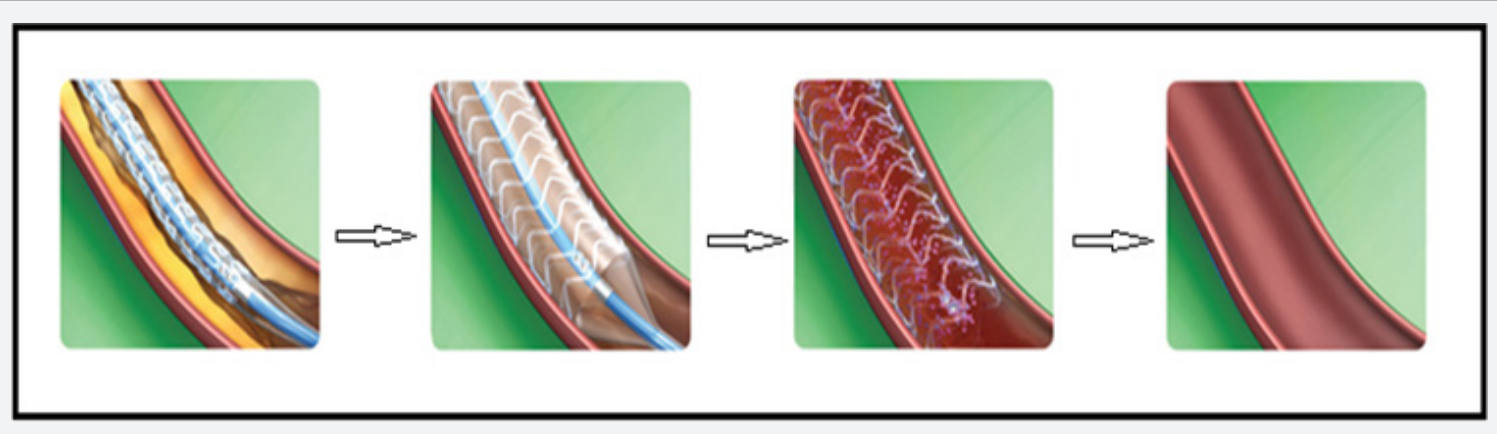

Figure 2: Fate of Bioresorbable vascular scaffold from implantation to complete biodegradtion in an implanted artery.

\section{Mechanism of Action of BVS}

As a fully BVS, functions very differently than a metal stentundergoing a series of physical changes, and leaving nothing behind. The revascularization phase is based on the principles of vascular restorative therapy (VRT)-that vessel radial support is needed for only a limited time. BVS provides the same vessel support and drug elution profile as the best-drug eluting stent [22-35]. Following Figure 3 shows the brief mechanism of action of BVS in an implanted coronary artery.

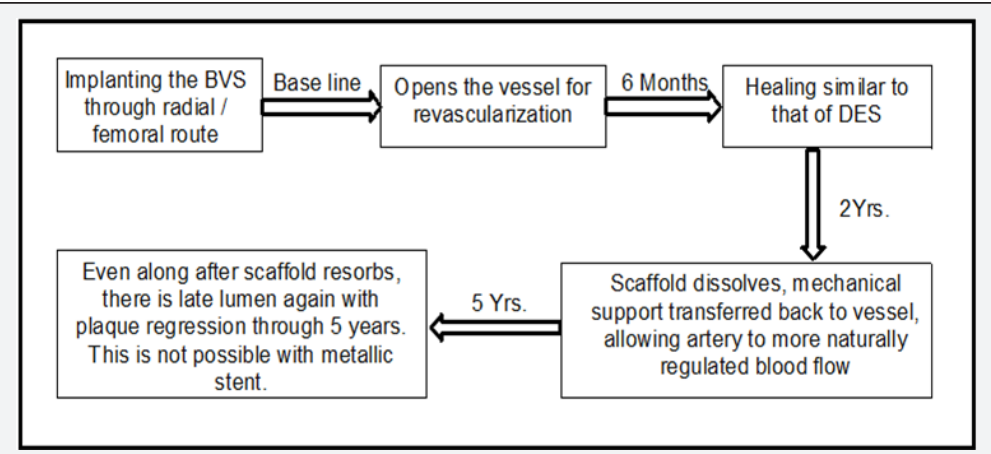

Figure 3: Mechanism of actiion of Bioresorbable vascular scaffold. 


\section{Advantages and Challenges of Bioresorbables Vascular Scaffolds}

In the following Table 1, we represented the most important advantages and challenges associated with BVS.

Table 1: Advantages and challenges associated with BVS.

\begin{tabular}{|c|c|}
\hline Ac & Challenges \\
\hline $\begin{array}{l}\text { Conformable and flexible to } \\
\text { preserve vessel geometry }\end{array}$ & $\begin{array}{l}\text { Developing a scaffold with } \\
\text { sufficient radial strength during } \\
\text { the critical time period }\end{array}$ \\
\hline \multirow{13}{*}{$\begin{array}{c}\text { Once resorbed: } \\
\text { •No foreign material left behind } \\
\text { •Restoration of functional } \\
\text { endothelial coverage } \\
\text { •Allows the restoration of } \\
\text { physiological vasomotion } \\
\text { •Allow to graft stented } \\
\text { segements of coronary artery } \\
\text {-Enables prevention of acute } \\
\text { recoil or occlusion } \\
\text { - Provide inhibition of insegment } \\
\text { restenosis through efficient } \\
\text { drug elution } \\
\text {-Improved subsequent coronary } \\
\text { imaging using multislice CT\& } \\
\text { MRI without artifacts } \\
\text { •Elevate any patient concerns } \\
\text { regarding permanent metal } \\
\text { implant in their bodies. }\end{array}$} & 0 \\
\hline & -Deliverability \\
\hline & $\begin{array}{r}- \text { Increase } \\
\text { thro }\end{array}$ \\
\hline & $\begin{array}{r}\text { - Longer durat } \\
\text { th }\end{array}$ \\
\hline & - Target lesio \\
\hline & \\
\hline & $\begin{array}{l}\text { as metal stents, which may result } \\
\text { in recoil and may require strong }\end{array}$ \\
\hline & $\begin{array}{c}\text { backbone, especially in small } \\
\text { vessels. }\end{array}$ \\
\hline & -These poly \\
\hline & $\begin{array}{l}\text { require special storage } \\
\text { and have a shorter } \mathrm{s}\end{array}$ \\
\hline & \\
\hline & $\begin{array}{l}\text { requires imaging quantitative } \\
\text { coronary angiography }(\mathrm{QCA})\end{array}$ \\
\hline & -High cost \\
\hline
\end{tabular}

\section{Adverse Events Associated with BVS}

From the clinical trials and real world experience of BVS, the adverse events that may be associated with treatment procedures and the use of a BVS in native coronary arteries include the following, but are not limited to allergic reaction or hypersensitivity to latex, device polymer and drug reactions to everolimus, anticoagulation or antiplatelet drugs, scaffold thrombosis (acute, subacute, late, very late), Stenosis or restenosis, Pericardial complications which may require additional intervention, including cardiac arrhythmias, cardiac ischemic conditions, cerebrovascular accident (CVA) and transient ischemic attack (TIA), system organ failures, cardiorespiratory arrest, and death [36-38].

\section{Composition of BVS}

The current BVS are composed of either a polymer or bioresorbable metal alloy. Numerous different polymers are available, each with different chemical compositions, mechanical properties and subsequently bioabsorption times. The most frequently used polymer in the current generation of BVS is PLLA. PLLA is already in widespread clinical use with applications such as resorbable sutures, soft-tissue implants, orthopedic implants, and dialysis media. The key mechanical traits for candidate material in coronary indications include high-elastic moduli to impart radial stiffness, large-break strains to impart the ability to withstand deformations from the crimped to expanded states and low-yield strains to reduce the amount of recoil and over inflation necessary to achieve a target deployment. Stent developers look to increase stent strut dimensions to compensate for mechanical shortcomings of bioresorbable materials. As the thickness of these struts increases, strain levels imposed on a material increase proportionally [39-42].

\section{BVS under Investigational, CE Marked and USFDA Approved}

The following Table 2 shows the BVS under Investigational and Regulatory clearance from EU and USFDA with their Technical features $[43,44]$.

Table 2: Shows the BVS under Investigational and Regulatory clerance from EU and USFDA with their Technical features.

\begin{tabular}{|c|c|c|c|c|c|c|}
\hline S.No & Name of BVS & Scaffold Material & $\begin{array}{c}\text { Medicinal } \\
\text { Product }\end{array}$ & $\begin{array}{c}\text { Strut } \\
\text { Thickness }(\mu \mathrm{m})\end{array}$ & $\begin{array}{c}\text { Resorption } \\
\text { Time(months) }\end{array}$ & $\begin{array}{l}\text { Regulatory } \\
\text { Status }\end{array}$ \\
\hline 1 & $\begin{array}{c}\text { Absorb BVS } 1.1 \\
\text { (Abbott Vascular) }\end{array}$ & PLLA & Evirolimus & 156 & $24-48$ & $\begin{array}{l}\text { FDA approved, CE } \\
\text { marked }\end{array}$ \\
\hline 2 & $\begin{array}{l}\text { ARTPBS(Arterial } \\
\text { Remodeling } \\
\text { Technologies) }\end{array}$ & PLLA & NONE & 170 & 42800 & CE marked \\
\hline 3 & $\begin{array}{c}\text { DREAMS 2G } \\
\text { (Biotronik SE \& } \\
\text { Co. KG) } \\
\end{array}$ & Mg alloy & Sirulomus & 150 & 9 & Investigational \\
\hline 4 & $\begin{array}{c}\text { DESolve } \\
\text { (Elixir Medical } \\
\text { Corporation) }\end{array}$ & PLLA & Myolimus & 150 & 43093 & Investigational \\
\hline 5 & $\begin{array}{l}\text { ART18Z scaffold/ } \\
\text { ART(Arterial } \\
\text { remodeling } \\
\text { technologies, } \\
\text { France) }\end{array}$ & $\begin{array}{l}\text { Poly-D-L-Lactic } \\
\text { acid }\end{array}$ & None & 170 & 24 & Investigational \\
\hline 6 & $\begin{array}{l}\text { DREAMS I } \\
\text { (Biotroniks) }\end{array}$ & Mg alloy & Paclitaxel & 125 & 12 & Investigational \\
\hline
\end{tabular}




\section{Issues Associated with the Marketed BVS}

The Absorb everolimus-eluting bioresorbable vascular scaffold (Abbott Vascular) was approved for use by the Food and Drug Administration (FDA) in July 2016. The largest trial of the Absorb Bioresorbable scaffold was the ABSORB III trial, which included 2008 patients. In the ABSORB III trial, the bioresorbable scaffold was found to be non inferior to the Xience everolimus-eluting metallic stent (Abbott Vascular) with respect to the composite end point of target-lesion failure (cardiac death, target-vessel myocardial infarction or ischemia driven target-lesion revascularization) at 1 year (with a rate of $7.8 \%$ with the Absorb scaffold vs $6.1 \%$ with the Xience stent, $\mathrm{P}=0.007$ for non inferiority). However, the rate of device thrombosis within 1 year after implantation was higher, although non significantly higher in the group that received bioresorbable scaffolds than in the group that received metallic stents $1.5 \%$ and $0.7 \%$, respectively, $\mathrm{P}=0.13$ ). In unpublished results at 2 years after implantation (reported at the 2017 meetings of the American College of Cardiology. The rate of target-lesion failure was significantly higher in the bioresorbable-scaffold group than the metallic-stent group $(11.0 \%$ vs $7.9 \%, P=0.03$ for superiority of the stent). These results show that BVS is generally comparable with the drug eluting stent when the device is placed in appropriately sized vessels and placed using appropriate procedural techniques. These findings have led the FDA to issue a safety alert for the Absorb bioresorbable vascular scaffold.

\section{Current status of Marketed BVS}

After the safety alerts from FDA Absorb BVS stents will no longer be supplying to non registry site in Europe that those sites should cease implantation and that remain BVS product will be removed by the Abbott vascular. With effective from May 31, 2017, the device will only be available in clinical register setting at selected sites or institutions that will play a pivotal role in the monitoring of this technology until summer 2018 at which time the situation will be reviewed [45]. Subsequently post marketing registries are being initiated in Europe and India to monitor implantation techniques for the Absorb dissolving stent, these E.U. registries will parallel post approval observational studies and training being conducted in other parts of the world including the ABSORB IV study of 3,000 Patients in the united states to conform the effect of current implantation technique on clinical outcomes [46-48].

\section{Conclusion}

With change in the life style of people affected by CAD and advanced in the technology for the treatment of CAD with interventional technologies for best outcomes, a hope is that a healed, normally functioning vessel free of foreign body and restenosis will be free of the risk of late thrombosis with the new generation devices like BVS.

\section{Acknowledgment}

Our special thanks to Prasanth .S, Blessy A. Daniel from S3V Vascular Technologies, Bangalore for their immense support and valuable suggestions throughout our review and we wish to thank our research guides, Prof. J. Vijaya Ratna, Dr. P. Shailaja, Andhra University College of Pharmaceutical Sciences for their effective guidance.

\section{References}

1. National library of medicine medlineplus, coronary artery glossary.

2. Coronary artery disease, WebMD, heart disease guide.

3. http://www.heartandvascularinstitute.net/services-procedures/ interventional-cardiology/pg2/\#PTCA

4. Condado JA, Waksman R, Gurdiel O, Espinosa R, Gonzalez J, et al. (1997) Long-term angiographic and clinical outcome after percutaneous transluminal coronary angioplasty and intracoronary radiation therapy in humans. Circulation 96(3): 727-732.

5. Teirstein PS, Massullo V, Jani S, Popma JJ, Mintz GS, et al. (1997) Catheter-based radiotherapy to inhibit restenosis after coronary stenting. N Engl J Med 336(24): 1697-1703.

6. Waksman R, Pakala R (2010) Biodegradable and bioabsorbable stents. Curr Pharm Des 16(36): 4041-4051.

7. Ormiston JA, Serruys PW (2009) Bioabsorbable coronary stents. Circ Cardiovasc Interv 2(3): 255-260.

8. Eterson KL, Nicod P (1997) Cardiac Catheterization. Methods, Diagnosis, and Therapy. Saunders ( $1^{\text {st }}$ edn.), Philadelphia, Toronto, Montreal, Sydney, Tokyo.

9. Topol EJ (2008) Textbook of Interventional Cardiology. Saunder $\left(5^{\text {th }}\right.$ edn.), Elsevier, Philadelphia, USA.

10. Krakau I (1999) Das Herzkatheterbuch. The Book of Cardiac Catheterization. Thieme Stutgart, New York.

11. Ormiston JA, Serruys PWS (2009) Bioabsorbable coronary stents. Circ Cardiovasc Interv 2(3): 255-260.

12. Waksman R (2006) Biodegradable stents: they do their job and disappear. J Invasive Cardiol 18(2): 70-74.

13. Finn AV, Joner M, Nakazawa G, Kolodgie F, Newell J, et al. (2007) Pathological correlates of late drug-eluting stent thrombosis: strut coverage as a marker of endothelialization. Circulation 115(18): 24352441.

14. Hoffmann R, Mintz GS, Dussaillant GR, Popma JJ, Pichard AD, et al. (1996) Patterns and mechanisms of in-stent restenosis: a serial intravascular ultrasound study. Circulation 94(6): 1247-1254.

15. Togni M, Windecker S, Cocchia R, Wenaweser P, Cook S, et al. (2005) Sirolimus-eluting stents associated with paradoxic coronary vasoconstriction. J Am Coll Cardiol 46(2): 231-236.

16. Barlis P, Tanigawa J, Di Mario C (2007) Coronary bioabsorbable magnesium stent: 15-month intravascular ultrasound and optical coherence tomography findings. Eur Heart J 28(19): 2319.

17. Cademartiri F (2007) Usefulness of 64-slice multi slice computed tomography coronary angiography to assess instent restenosis. J Am Coll Cardiol 49(22): 2204-2210.

18. Erbel R, Di Mario C, Bartunek J, Bonnier J, de Bruyne B, et al. (2007) Temporary scaffolding of coronary arteries with bioabsorbable magnesium stents: a prospective, nonrandomised multicentre trial. Lancet 369(9576): 1869-1875. 
19. Eggebrecht H, Rodermann J, Hunold P, Schmermund A, Böse D, et al. (2005) Images in cardiovascular medicine. Novel magnetic resonancecompatible coronary stent: the absorbable magnesium-alloy stent Circulation 112(18): e303-e304.

20. Okamura T, Onuma Y, García-García HM, Regar E, Wykrzykowska JJ, et al. (2010) 3-Dimensional optical coherence tomography assessment of jailed side branches by bioresorbable vascular scaffolds: a proposal for classification. JACC Cardiovasc Interv 3(8): 836-844.

21. Serruys PW, Ormiston JA, Onuma Y, Regar E, Gonzalo N, et al. (2009) A bioabsorbable everolimus-eluting coronary stent system (ABSORB): 2-year outcomes and results from multiple imaging methods. Lancet 373(9667): 897-910.

22. Ellis SG, Ellis SG, Kereiakes DJ, Metzger DC, Caputo RP, et al. (2015) Everolimus-Eluting Bioresorbable Scaffolds for Coronary Artery Disease. N Engl J Med 373(20): 1905-1915.

23. Ong P, Athanasiadis A, Perne A, Mahrholdt H, Schäufele T, et al. (2014) Coronary vasomotor abnormalities in patients with stable angina after successful stent implantation but without in-stent restenosis. Clin Res Cardiol 103(1): 11-19.

24. Serruys PW, Garcia-Garcia HM, Onuma Y (2012) From metallic cages to transient bioresorbable scaffolds: change in paradigm of coronary revascularization in the upcoming decade? Euro Heart J 33(1): $16 \mathrm{~b}-25 \mathrm{~b}$.

25. Serruys PW, Onuma Y, Garcia-Garcia HM, Muramatsu T, van Geuns RJ, et al. (2014) Dynamics of vessel wall changes following the implantation of the absorb everolimus-eluting bioresorbable vascular scaffold a multi-imaging modality study at 6, 12, 24 and 36 months. Euro Intervention 9(11): 1271-1284.

26. Simsek C, Karanasos A, Magro M, Garcia-Garcia HM, Onuma Y, et al. (2016) Long-term invasive follow-up of the everolimus-eluting bioresorbable vascular scaffold: five-year results of multiple invasive imaging modalities. Euro Intervention 11(9): 996-1003.

27. Serruys PW, Chevalier B, Dudek D, Cequier A, Carrié D, et al. (2015) A bioresorbable everolimus-eluting scaffold versus a metallic everolimus-eluting stent for ischaemic heart disease caused by denovo native coronary artery lesions (ABSORB II): an interim 1-year analysis of clinical and procedural secondary outcomes from a randomised controlled trial. Lancet 385(9962): 43-54.

28. Lane JP, Laura ELP, Alexander JS, Erica JP, Michael PF, et al. (2014) Lumen Gain and Restoration of Pulsatility after Implantation of a Bioresorbable Vascular Scaffold in Porcine Coronary Arteries. J Am Coll Cardiol Intv 7: 688-695.

29. Otsuka F, Pacheco E, Perkins LE, Lane JP, Wang Q et al. (2014) Longterm safety of an everolimus-eluting bioresorbable vascular scaffold and the cobalt-chromium XIENCE V stent in a porcine coronary artery model. Circ Cardiovasc Interv 7(3): 330-342.

30. Serruys PW, Onuma Y, Dudek D, Smits PC, Koolen J, et al. (2011) Evaluation of the second generation of a bioresorbable everolimuseluting vascular scaffold for the treatment of de novo coronary artery stenosis: 12-month clinical and imaging outcomes. J Am Coll Cardiol 58(15):1578-1588

\section{Serruys PW (2015) Absorb Cohort B TCT}

32. Bartorelli A (2015) Absorb Extend. TCT.

33. Chevalier BR (2015) Absorb II 2 Year. TCT.

34. Kereiakes D (2015) Absorb III 1 Year. TCT.

35. Ellis SG, Kereiakes DJ, Metzger DC, Caputo RP, Rizik DG (2015) Everolimus-Eluting Bioresorbable Scaffolds for Coronary Artery Disease. N Eng J Med 373(20): 1905-1915.

36. Kimura T, Kozuma K, Tanabe K, Nakamura S, Yamane M, et al. (2015) A randomized trial evaluating everolimus-eluting Absorb bioresorbable scaffolds vs. everolimus-eluting metallic stents in patients with coronary artery disease: ABSORB Japan. Euro Heart J 36(47): 33323342.

37. Gao RL (2015) ABSORB China 1 Year. TCT.

38.(2014) ABSORB IV trial under way; ClinicalTrials.gov Identifier: NCT02173379.

39. Ellis SG, Kereiakes DJ, Metzger DC, Caputo RP, Rizik DG, et al. (2015) Everolimus-eluting bioresorbable scaffolds for coronary artery disease. N Engl J Med 373(20): 1905-1915.

40. Ellis SG, Kereiakes DJ, Stone GW (2017) Everolimus-eluting bioresorbable vascular scaffolds in patients with coronary artery disease: two-year outcomes from the ABSORB III trial. Presented at the Scientific Sessions of the American College of Cardiology, Washington, DC, USA.

41. (2017) Absorb GT1 Bioresorbable Vascular Scaffold (BVS) by Abbott Vascular: letter to health care providers-FDA investigating increased rate of major adverse cardiac events.

42. Onuma Y, Serruys PW (2011) Bioresorbable Scaffold: the Advent of a New Era in Percutaneous Coronary and Peripheral Revascularization circulation 123(7): 779-797.

43. Brodie BR, Pokharel Y, Garg A, Kissling G, Hansen C, et al. (2014) Very late hazard with stenting versus balloon angioplasty for ST-elevation myocardial infarction: a 16-year single-center experience. J Interv Cardiol 27(1): 21-28.

44. Waksman R, Pakala R (2010) Biodegradable and Bioabsorbable stents. Curr Pharm Des 16(36): 4041-4051.

45. (2017) Status of the "Disappearing stent" in Europe: It's complicated!

46. (2017) Katherine Davis, ACC.17: ABSORB III trial shows stent associated with increased risk of adverse outcomes.

47. Larry Husten (2017) ABBOTT Pulls troubled ABSORB stent from European market.

48. (2017) Shardul Nautiyal, DCGI starts evalution of safety data related to BVS, Cardiac stents following their restricted use, pharmabiz.com. 

(C) Commons Attribution 4.0 License

DOI: $10.19080 /$ JOCCT.2017.06.555687

\section{Your next submission with Juniper Publishers} will reach you the below assets

- Quality Editorial service

- Swift Peer Review

- Reprints availability

- E-prints Service

- Manuscript Podcast for convenient understanding

- Global attainment for your research

- Manuscript accessibility in different formats

( Pdf, E-pub, Full Text, Audio)

- Unceasing customer service

Track the below URL for one-step submission https://juniperpublishers.com/online-submission.php 